\title{
What Does 'Lügenpresse' Mean? Expressions of Media Distrust on PEGIDA's Facebook Pages
}

Kristoffer Holt, Associate Professor, Department of Media and Journalism, Linnoeus University

André Haller, Assistant Professor, Institute for Communication Science, University of Bamberg

In this article, we analyze the protest movement PEGIDA's criticism of the press (i.e. 'Lügenpresse', the 'liar press') on Facebook. What are the main points of criticism of the press and what are the reasons expressed for this criticism, and how do they refer to traditional media in the postings? We conduct a qualitative content analysis of PEGIDA's Facebook pages in Germany, Austria, Sweden, and Norway. The study shows that there are two main types of references: affirmative references to prove one's own positions and contesting references which comprise media criticism.

\section{Introduction}

The liar press-shouts during the rallies of the right-wing populist movement PEGIDA (abbreviation for 'Patriotic Europeans against the Islamization of the Occident) in Germany condense one of the most dominating discourses not only in Germany but also in other countries. The question if mainstream media reports accurately and does a full coverage including different standpoints, especially concerning political issues, is in the middle of this debate. Especially right-wing populist politicians and activists claim that established media lies in the coverage of migration politics. Journalists are seen as part of the elite, besides the political establishment or other elite persons and organizations like international bank houses, and are therefore defined as enemies in populist ideology. Populist communication tries to appeal to the 'pure people' and to separate them from 'the elite' and social outgroups such as migrants, long-time unemployed people and others (Jagers and Walgrave 2007). The aversion against journalism expresses itself not only in 'liar press' shouts of protesters but also in right-wing party 
politics: Frauke Petry, a former politician of the German party Alternative for Germany, persistently calls established journalism 'Pinocchio press. Also, physical attacks on journalists are reported and condemned by professional organizations (BDZV 2016). In Sweden, the Sweden Democrats have for long been treated more negatively by journalists than other parties and have successfully been able to use the victimization by mainstream media as a rhetorical resource (Hellström and Lodenius 2016).

PEGIDA's allegations include critique on the trustworthiness of journalistic products as well as on an assumed limitation of political diversity in media coverage. Empirical research shows that established journalists are not always used as an enemy in populist discourse. In many cases, the populist movement even used mainstream media coverage to underline their own political positions (Holt and Haller 2016). However, media distrust remains a central category in populist right-wing discourse. But how exactly PEGIDA relates to mainstream media has not been investigated yet. This paper uses a qualitative content analysis of the PEGIDA Facebook pages of its outlets in Germany, Austria, Sweden, and Norway. We analyzed postings from June 1st until September 30, 2015 to identify the patterns of media criticism used in the online communication of the movement in order to answer our research question (RQ): How are references to mainstream media used on the PEGIDA Facebook pages in Germany, Austria, Sweden, and Norway?

Media distrust, populism, and alternative media

In recent years, Europe has seen the rise of populism as well as various alternative media that express anti-system, anti-establishment and anti-immigration sentiments (Aalberg, Esser, Reinemann, Stromback, and De Vreese 2016; Holt 2016). These media present alternative interpretations of political and social events and try to influence public opinion according to agendas that are mainly critical of immigration politics and the perception of an imminent threat of Islamization of European countries - although the main focus of criticism and level of 'anti-systemness' (Capoccia 2002) varies greatly among different outlets. Additionally, the intensity of criticism also varies greatly between them, making it difficult to talk about a specific and well-defined new type of alternative media. Nevertheless, as in the Swedish case, a number of alternative media outlets (especially online) with a specific focus on a) criticism of Swedish immigration policy and b) of how this issue is treated in mainstream media have become visible enough to attract much attention and cause intense debates within the mainstream media (Truedson 2016). These alternative media often accuse traditional media of: being biased against any immigration-critical perspective, covering up problems related to immigration, and ostracizing individuals who espouse political views deemed controversial (Holt 2016). What distinguishes these alternative media from other social or participatory media is their clear and outspoken aim to blame, 
critique and sometimes even undermine trust in established media. These media outlets are not always purely ideological in a traditional sense, although there are many with outspoken sympathy for right-wing extremism. Their ideological focus is not, however, limited to far-right activism. Those active in these environments represent positions along a very wide spectrum - from neo-Nazis and fascists through right wing populists to moderates and social democrats (Holt 2016). As an alternative media channel, and given the fact that the PEGIDA movement expressly avoids contact with mainstream media, the movement's Facebook pages can be placed within this broader context of immigration critical alternative media.

Since there is a lack of research and knowledge specifically about these media, political as well as scholarly debates about such media channels can (and tend to) be somewhat crippled by indignation and polemics (Taguieff 2015), rather than based on facts and systematic observations. In order to understand why these media are appearing in Europe and seem to be successful in their communication, it is necessary to study the whole range of political expressions related to immigration-critical perspectives and media skepticism, especially in the context of the "new technological affordances epitomized by Web 2.0". (Alvares and Dahlgren 2015). The criticism from these alternative media regarding the way that mainstream media works cannot be brushed off as a minimal and peripheral phenomenon; they represent perspectives that echo across the European political scene as well the American, where President Donald Trump employs similar arguments (Trump 2016). Tsfati (2003, p. 67) defines media skepticism as a sense of "alienation and mistrust toward the mainstream media". It involves the "feeling that journalists are not fair or objective in their reports about society and that they do not always tell the whole story" and that mainstream journalists "will sacrifice accuracy and precision for personal and commercial gains" (Tsfati 2003, 67). A recent study shows support for the hypothesis that online news-consumption from alternative sources through social media negatively affects the level of satisfaction with democracy, and the authors refer to interaction with "anti-system" views as an explanation (Ceron and Memoli 2015). In this paper, our aim is to study and describe this criticism as it is visible through the way PEGIDA relates to mainstream media in their Facebook postings, in order to contribute to a better understanding of how media criticism is expressed by populist movements on social media.

Paradoxically, the relationship between populist players and alternative media on the one hand, and mainstream media on the other, is not entirely one of contestation and antagonism. Populist politicians need the mainstream media both as opposing poles in their rhetoric and as vehicles for their message. The connection between these movements and the established media is therefore more complex because any movement needs publicity (Mazzoleni 2014). Also, recent studies have shown that alternative media are highly dependent on mainstream media for material to write about and to comment on; in order for there to be an alternative, the original must be in place and active (Holt 2016). 


\section{Methodology}

The strategic communication of the PEGIDA movement almost exclusively takes place via Facebook pages as the leaders refuse to talk to established media. For instance, PEGIDA Germany does not operate a genuine website. In the beginning of the movement, the URL www.pegida.de linked to the Facebook account @pegidaevofficial, which is the most important communication platform of the protesters. Since right-wing populist movements often express anti-mainstream media resentments that may lead to a non-use of traditional PR instruments such as press conferences or news releases, political communication research has to focus on optional communication channels such as social network sites.

Since there is less research on manifestations of media distrust and criticism of established media by populist social movements, an explorative approach is useful. In a recent study (Holt and Haller 2016), we found that PEGIDA pages in different countries often refer to news articles of established media in an affirmative fashion, for example by pointing out that a mainstream newspaper article states something that strengthens their own arguments. However, a closer qualitative research has not yet been made. Our approach in this study focuses on a qualitative content analysis of the postings on the official Facebook sites of the movement to find out how PEGIDA outlets substantiate the 'liar press' accusation. Media distrust can be expressed by different allegations. Some critiques argue that journalists hide facts that could be considered opportune to a right-wing populist agenda, such as hiding crime statistics of migrants. Other accusations claim that there is an exclusion of some political camps such as right-wing movements, parties or politicians. The most aggressive allegations are that mainstream media journalists intentionally lie in terms of presenting wrong information on topics, especially concerning migration. The qualitative content analysis focuses on the type of media distrust in the postings of the movement. The coding was conducted by using the qualitative research software MAXQDA. All posts containing references to traditional media, online and offline, were identified and part of the qualitative analysis. 'References' can be differentiated between explicit and implicit references:

1) An explicit mention of traditional media can be identified when media companies or journalists are explicitly named, for example: 'According to an article of SPIEGEL Online' or 'a journalist from the ARD TV show'. Hyperlinks to mainstream media products are also counted as explicit references.

2) An implicit mention occurs when traditional media outlets are not 
named but addressed as a whole, for example as 'liar press', 'the mainstream media', 'Pinocchio press', 'established media' or 'journalistic elite'.

The four countries we have selected are examples of countries where the emergence of a movement like PEGIDA, and their brand of populism, constitutes a sharper contrast to the mainstream/elite attitude toward immigration (and Islam in particular) upheld in public discourse by influential parties than in many other European countries. This is most evident in Germany and Sweden - countries who have differed mostly from most European countries in this respect - but it also goes for Austria and Norway to a lesser degree (Berry, Garcia-Blanco, and Moore 2016). The self-appointed position as outsider, rebel and voice of marginalized opinions is highlighted in such settings and motivates the study of how they relate to mainstream media in these countries. Since there are also differences between the countries in these matters, a comparison is made between them.

Overall, the sample includes 892 postings (Germany: 351; Austria: 384; Sweden: 106; and Norway: 51). After identifying the posts with references to mainstream media the sample was reduced to 348 postings (Germany: 151; Austria: 151; Sweden: 25; and Norway 21). Converted to percentages, $43 \%$ of the German, $39 \%$ of the Austrian, $26 \%$ of the Swedish and $41 \%$ of the Norwegian sample contain at least one reference to mainstream media. After picking out relevant postings with references to traditional media and importing them to MAXQDA, we analyzed the objects. The research focus was on the actual use of the media references: We investigated how the references were used and whether the usage fulfilled a strategic function. It was assumed that the PEGIDA pages mainly criticized mainstream media as an opposing actor for political reasons.

Our sample contains all postings of the official PEGIDA Facebook pages from June 1 st until September 30 in the most intense phase of the refugee crisis of 2015. The German sample must be seen as a special case for several reasons: PEGIDA emerged in Germany and was topic of international media coverage, especially in 2015 when the participant numbers rose up to 20.000-25.000 (Durchgezaehlt.org 2016). ${ }^{1}$ Besides, the German PEGIDA page is by a large margin the most successful page in the sample in terms of 'likes'. In the empirical analysis and particularly in the interpretation of the findings it has to be noted that the Scandinavian pages do not have that range (the Swedish page had 1.325 'likes' and the Norwegian had 5.143). In July 2016 the German page had about 205.000 'likes'. A quite impressive number: Chancellor Merkel's CDU (Christian Democratic Union) had about 123.500 'likes' and the SPD (Social Democrats) 120.000 in December 2016. The German page was also in the center of a

\footnotetext{
${ }^{1}$ Social movements are difficult to analyze as there is no registration process in the most cases. We also have different sources counting the numbers of protest marchers. The website Durchgezaehlt.org shows all trustworthy sources and statistics.
} 
conflict between PEGIDA and Facebook. After complaints of users the original page was shut down in July 2016 (SZ-Online 2016) but was re-established as a new site.

\section{Empirical Findings}

In this chapter we will present the qualitative findings of the study. Each subchapter will first describe an overall theoretical consolidation. In a second step examples from each investigated country will illustrate the theoretical assumptions. Actually, the study identified the assumed 'liar press' accusation by the right-wing populists. Nevertheless, we found another communicative pattern regarding media references, namely affirmative ones. A third type of references was neutral or could not be coded unambiguously. For a better transparency and understanding, all selected posts in the following were translated into English by the authors.

\section{Affirmative References}

Contrary to the thesis of a dominance of media criticism or distrust, the qualitative analysis revealed an affirmative pattern. These types of references are used to 'prove' own political standpoints of the page producers. Some articles substantiated PEGIDA's positions, for example by showing statistics on migration or by citing politicians or experts who criticize migration policies.

\section{Germany}

The simplest type of affirmative references are articles to topics including crime caused by immigrants or terrorism. On June 26th the German PEGIDA page linked to breaking news of the magazine Focus about the Islamic terror attack on a tourist hotel in Tunisia. The producers of the page affirmed their fears with the words: "And it goes on, take care guys, the sleeper cells can be everywhere!" Another link to the newspaper Die Welt from September 3rd was about the Norwegian intelligence warning of ISIS and Al Nusra terrorists who could use refugee trails to enter Europe. Affirmative references were not only about crime but also contained critique on the refugee policy. There are illustrative examples for that: On September 3rd PEGIDA linked to MDR, a German public service TV station. It reported about the trade with Syrian passports in Germany. A second article underlined that political problem in the newspaper Die Welt. It reported about a Dutch journalist who bought a fake Syrian passport with the portrait and the personal information of the Prime Minister of the Netherlands, Mark Rutte. There are further references which were used to prove a failed immigration policy in other areas: A link to the local newspaper $S H Z$ lead to an article about Denmark closing its borders 
(September 9th). The post is accompanied by the text: "Denmark shuts down...it is colorful enough." In the German right-wing sector the word "colorful" (German: "bunt") is regularly used in a sarcastic way to make fun of (mainly left-wing) people demanding a high diversity of cultures in the country. PEGIDA's criticism also concerns concrete political areas, for instance labor market policy. An article of the weekly newspaper Die Zeit cited the German Employment Minister, Andrea Nahles with the words "The Syrian Doctor is not the usual case." (September 10th). In the lead of the posting the administrators of the page are agitating against asylum seekers. Like in many other posts of the German page there is also an insult against Sigmar Gabriel, former leader of the Social Democrats (SPD), who is named as "\#FastSonderSchülerSigmar" in reference to Gabriel's statement that a former teacher wanted him to go to a special-needs school.

Austria

Like in the case study of Germany, we also found affirmative references on the Austrian page. One type of 'positive' references are posts of mainstream media articles citing politicians or experts with similar or same political positions to those of PEGIDA. An online text of the Austrian quality newspaper Die Presse was posted on July 9th: The text cited Heinz-Christian Strache, frontman of the right-wing populist Austrian Freedom Party (FPÖ). The text is about the discussion on financial help for Greece. Strache demands a referendum of the Austrian people before the government would send money to the indebted country. The introductory text of the posting highlights Strache's quote and a part of the article. A second type of affirmative references concerns statistics that support PEGIDA's positions on migration. On September 10th the movement uploaded an article of Heute, a large giveaway newspaper in Austria. The article shows a statistic on financial family assistance for immigrants: "223 million euros flowed abroad in 2014". The post implicitly assumed that immigration costs Austria millions of euros.

Besides texts which are used to prove one's own position, we see another type of affirmative reference: One posting referred to the newspaper Augsburger Allgemeine and was about the plan of PEGIDA Germany to run in the 2016 state elections (regional elections) in Germany (July 8th). The article cited one of the most prominent leaders of PEGIDA, Lutz Bachmann. In a speech at a rally in the city of Leipzig, he said that PEGIDA would try to get direct mandates to overcome the five-percent threshold needed to gain seats in the state parliaments ('Landtage'). That posting shows that affirmative references are not only about certain political issues but also concern organizational aspects. The communicative purpose could be to show the Austrian supporters that the right-wing populist movement has a clear political strategy.

In three cases the Austrian page posted letters to the editor of mainstream media dealing with the asylum crisis (two letters) and the fear of terrorism. All texts were published in 
the leading Austrian tabloid Krone in the column 'The Free Word' ('Das Freie Wort'). On June 29th a reader criticized the Austrian Minister of the Interior who said that terrorism in France and Tunisia would "have no connection to Austria". The writer complains about the wording of Islamic crimes which would be called 'psychotic' and not as terrorist attacks. The other letters made the asylum crisis a subject of discussion. On July 26th a reader wrote about asylum seekers which complained about the conditions in the Austrian refugee camp in Traiskirchen: "Therefore my question to all of those asylum seekers: Why are you here, more specifically why are you not going somewhere else if you do not like the care in Austria?". The third letter (August 9th) built up a conflict between the political class and the people in the asylum discussion: "What is happening right now is pure dictatorship and the bill will be presented in the end. Look at the opinion polls! Dear guys, you are ruling in the wrong direction against us Austrians!". The use of letters to the editor may be to produce a 'community feeling' in the right-wing sphere. By showing letters of normal media recipients creates the impression that PEGIDA's claims 'match up' with the political standpoints of the recipients. However, all three texts are similar to PEGIDA's claims in content and tone.

\section{Sweden}

As shown in a previous study, the Swedish page is more oriented towards communication directly with supporters than the other countries, for example with information about a planned rally or about the leadership of the movement or with direct calls for actions (for example 'share this post'). Sweden also stands out against the other three countries referring to traditional media less frequently (and to alternative media more frequently) than the other countries (Holt and Haller 2016). Here we have looked more specifically into the nature of the references to traditional media. When it comes to the affirmative references, we found that they fall into the same patterns as described above with the German and Austrian cases. On the 2 August, 2015, for example a posting contained a shared article from the Swedish Public Service TV broadcaster $(S V T)$, with a debate article arguing against a proposal for introducing separate opening hours for men and women at certain public pools. In this case it is clear that the posting of this article is a statement of support for the debater who clearly opposed such Islamic influence on Swedish public life. Other postings contained articles from traditional media with statements or information that problematizes Islamic organizations or pointed to the threat of Islamic terrorism or Swedish unpreparedness for crime committed by Muslim immigrants. One post contained a link to an article by a local tabloid where the view on women and equality presented on various Muslim online resources in Sweden is criticized. Another example is a link to a morning newspaper with an article about the police inability to deal with crime in certain problematic areas where many immigrants live. One posting was a link to an article in a national tabloid Expressen about how ISIS is smuggling terrorists into 
Sweden. The references to traditional media on the Swedish page were almost exclusively posted just as links - without any comments.

\section{Norway}

The Norwegian page contained many references with added comments from the one who posted. On the $18^{\text {th }}$ of June, for example, the posting contained a reference to an article in the business newspaper Finansavisen and an article that compared the cost of accepting refugees from Syria into Norway with the cost of sending aid to the region. PEGIDA Norway comments: "The cost for one Syrian refugee is 7 million crowns!". Other affirmative postings of links to mainstream media mainly deal with news that are presented as support for a critical stance against Islam, like reports about the persecution of Christians in Islamic countries or negative effects of immigration for Norwegians (such as for example cut downs in the care for the elderly made in order to accommodate refugees).

\section{Contesting References}

Our first working hypothesis claimed that there will be mostly anti-media postings on all PEGIDA pages in the sample. Theoretical works suggest that media criticism is an integral part of an anti-elite strategy of populist communication. Actually, there are many contesting references which will be shown below.

\section{Germany}

Some contesting references in the German sample used mainstream media content as a basis to contest opposing positions. An online article of the private news channel $N-T V$ featured an interview with the CEO of Daimler Benz, who said that "most of the refugees are young, well-educated and highly motivated. Precisely the type of people we are looking for." (September 6th). PEGIDA then called him a hypocrite as Daimler would not build any factories in Africa which would stop emigration from the continent. Another post linked to an article of the Sächsische Zeitung and was about rumors that asylum seekers would be allowed to steal in supermarkets. The producers of the Facebook page commented on that and claimed that the newspaper was owned by the Social Democratic Party: "Really a great and calming journalistic investigation" followed by laughing emoticons. It is obvious that PEGIDA questioned the trustworthiness of the report. This example shows that the right-wing group tries to build up a political-medial complex which can also be observed on a macro level (see below). A further disagreement with a professional can be seen on June 9th: After riots 
by left-wing extremist in Leipzig a scientist said in the newspaper Freie Presse that more policemen could "heat up the atmosphere" at demonstrations. In that case PEGIDA also uses a sarcastic reply: "Consequently less police would mean that the SAntifa picks up little flowers, we understood Professor Pickel...”. Like in other cases PEGIDA creates a compound word: 'SAntifa', which contains 'Antifa' as the abbreviation for anti-fascist movements and 'SA' which stands for the Sturmabteilung, a paramilitary group in the Third Reich. Once again, a separation into 'the people' and a social outgroup, the anti-fascists, is made including criticism of the elite personalized by a scientist was made.

In addition to attacks against specific media outlets there are posts expressing critique to established media in general. It is striking that the German page often uses the word 'liar press' to label mainstream media as untrustworthy information sources (for example on September 3rd, 4th, 11th, 14th, 16th or 18th). The liar press allegation is often accompanied by insults such as the word '\#Journaille' which is a degrading German term for journalism. On September 19th PEGIDA wrote: "The following applies for every \#journaille of that kind, you have to hit the \#presstitutes where it hurts the most.". 'Presstitutes' is a compound word of 'press' and 'prostitutes' which indicates an assertion that journalists are corrupt. The German PEGIDA page often uses caricatures showing a right-wing world views. A cartoon from September 2nd shows journalists in training with an instructor saying: "You are writing 'left march'? Everyone who is neglecting the teaching content is fired!". There is also an attempt to create some kind of a counter-public in a posting on September 2nd when PEGIDA linked to a live video stream in Budapest to show live pictures of refugees in the Hungarian capital. In that posting the movement claimed that "the \#presstitutes of the \#journaille" deliberately choose images of children to manipulate the public.

Austria

Most cases of contesting posts concern dissent with the content of mainstream media articles, for example on July 22nd, August 17th, 18th or September 24th. The reference from July 22nd is an article to the German news magazine Focus on Islamic religious education in Germany. PEGIDA Austria criticizes that concept in a satirical way: "Seriously, with an alleged minority of 4.2 million Muslims in Germany this is absolutely unnecessary, or have we been lied to for decades?". The example from August 18th is an interview with a social scientist published in the Austrian newspaper Der Standard. In the text, the researcher claims that we witness the "most qualified immigration ever". PEGIDA opposes the statement and proposes a policy which takes care that people do not have to flee to Europe if their home countries would be more livable. A third example is a graphic of the Austrian Television which shows a quote of the chairwomen of the Green Party in Austria, Eva Glawischnig, who said that she wants to integrate the burka to the Austrian society. PEGIDA comments on that: "The 
chairwomen of the Greens Eva Glawischnig integrates the burka into Austria. Or Austria into the burka. Only she knows precisely!". There is also direct criticism of specific media outlets. On September 4th a link to a TV interview aired on Austrian Television $(O R F)$ was commented by PEGIDA: "The ORF did not expect that a Middle East expert gives answers to mass migration to Europe which the red broadcasting (in German the term "Rotfunk" indicates a left-leaning medium) has not expected!".

Besides contesting references, we also find postings showing an overall claim against mainstream media. These are postings which are not necessarily naming specific media institutions but which are displaying media criticism in general. Negative references of that type are sometimes made by posting wall charts claiming that media is an "agitator" (September 24th), "hides" (September 12th) information, or manipulates the coverage by only showing "dead children or women" (September 5th) as refugee victims. Some cases indicate that the Austrian producers try to build up the classical populist triad (Jagers and Walgrave 2007, p. 323) of 'the people' against 'the elites', consisting of politicians and the media, and against 'social outside groups' which are supposed as a threat to the 'heartland' (Mudde 2004, p. 543), mainly Muslim migrants (August 17th, 28th and September 10th). An example from September 24th summarizes all three social groups of populist discourse in a wall chart: "Big thanks to everybody who has the courage to speak about problems in our asylum policy. Thank you for resisting the agitation of the media, celebrities, the lefts, the greens and other dogooders. Keep it up! You are not alone!". Like in the German sample, there are also allegations of an influence of the government on public broadcasting, for instance on August 22nd: The page links to an article of a right-wing alternative website blaming the Austrian Television not to reveal the origin of a band of robbers in Vienna. Another post from September 10th blames the $O R F$ to be an institution of "state propaganda" and calls the public service broadcaster "state broadcaster" (in German: "Staatsfunk" in terms of an official propaganda channel of the ruling class).

\section{Sweden}

The contesting references on the Swedish PEGIDA page were rare. The examples we found mostly contained indirect contesting references where articles from immigration critical alternative media were cited and where mainstream media is criticized. One example is a link to a video from the American alternative site Clashdaily.com, telling the story of a young girl who was raped by Muslim immigrants. The highlighted preamble states: "This is exactly what the media does not want you to know.". Another posting consisted of a link to an article at Pamelageller.com with the title: "Media BLACKOUT on MASSIVE PROTEST Against Muslim Migrant Invasion of Europe.”. There were no postings at all containing comments by PEGIDA Sweden.

Norway 
The contesting references to mainstream media found on the Norwegian page were either arguments against statements and opinions presented in newspapers or contained critical remarks about the media per se. One post dealt with the fact that the PEGIDA movement is widely described as right-wing extremist in the mainstream media and countered by referring to humanist values. Another posting linked to an article in the daily newspaper Dagbladet.no with the title "A good investment for Norway" - pointing to immigration as an investment to counter the demographic trend of a decreasing population in Norway. PEGIDA Norway comments: "Is this irony?", and present statistics for the employment rate for immigrants from several Muslim countries. Another type of contesting reference deals with how the media work. In relation to an attempted rape case, where the suspects were described as North Africans in mainstream media, a debate followed about whether or not to disclose such information. PEGIDA Norway exclaims: "Enrichment! Attempted rape! Multiculture!", blaming Norwegian politicians and media paving the way for such behavior by being overly cautious in these matters.

\section{Discussion}

Overall, we identified two strategic patterns of PEGIDA's online communication: Firstly, affirmative references (references used in an affirmative way, as proof of own positions or support for stated opinions). Against our first working hypothesis, there were not only contesting references to established media which would have confirmed theories of populism assuming that populists are dependent on the antipode against elite institutions like media organizations (Mudde 2004; Jagers and Walgrave 2007). Secondly, we found contesting references criticizing mainstream media. Contesting references can be separated into two sub patterns: The first type comprises of 'liar press' allegations in general. As the qualitative analysis shows, criticism of 'the liar press', 'the state media' or 'the red broadcast' reveal a deep-rooted skepticism visible on the PEGIDA Facebook pages in all four countries. The second sub pattern contains opposing opinions to media information, for instance disagreement with statements of public figures speaking in the media. In this respect, Germany, Austria, and Norway follow a similar pattern, where comments accompany links to articles containing statements in mainstream media, while the Swedish page more passively posts links to content in other media.

The occurrence of affirmative references to mainstream media shows the complexity of populist communication as well as its relationship to established media organizations. On the one hand, an alternative media sphere was established in the last years with a high reach in some instances. If we look at Germany we see a wide range of right-wing alternative media projects like Politically Incorrect (PI News), Compact magazine, Junge Freiheit and the publishing house Kopp. These publishers are, because 
of their wide reach, rather successful in the right-wing sector. In addition to that, the publishers mentioned above offer a broad spectrum of content, for example: articles, videos, books, or conferences. Consequently, Storz $(2015,7)$ believes there is "communicative full service" in the right-wing public sphere. Despite of the emergence of right-wing media, our findings show that populist communication depends on the supply of information by established media houses since right-wing alternative media do not have the financial and personnel resources for 'real' journalistic work. Besides, the use of mainstream media content may lead to a higher credibility among the public.

Restrictions of the study

This paper presented an exploratory study to discover possible relationships between populist social movements and established media. Therefore, a qualitative approach was used in order to focus on the content and the language of the PEGIDA postings. We tried to present our methodology and findings as transparent as possible. However, there are some restrictions of the study which have to be considered in the valuation of the findings. As in other online content analysis, we cannot guarantee that the content was not modified since we saved the material on a fixed date. Almost all online content is characterized by a high transitoriness and dynamicity. There is also a problem concerning the multimediality and multimodality of online content (Wünsch and Welker 2010, 497): Facebook posts do not only contain texts but also videos, images and other visual material such as emoticons, visual memes or gifs. Though we also tried to include ironic and sarcastic visual statements, our study mainly focused on the textual part of the material.

Furthermore, the methodological design of the study was based on theoretical assumptions of the relationship between populism and the media. After a first analysis, we decided to use a qualitative content analysis to determine main categories of populist references to mainstream media actors. Hence, the presented study must be seen as a preliminary study for a quantitative content analysis. Due to limited personnel resources the paper is limited to the Scandinavian, German and Austrian case studies. Hence, the study cannot claim to be applicable for other countries as well as for other types of populist web presences. Nevertheless, our theoretical classification is useful and can be used in further research projects on populist online communication.

Concluding remarks and outlook

This paper tries to answer the question of how right-wing populist movements relate to and criticize established media. We therefore analyzed the Facebook communication of the right-wing movement PEGIDA in Germany, Austria, Sweden, and Norway. As 
stated above, there is an alternative media sphere being established in the populist sector. In the European case, these communicative services are not as powerful as mainstream media. However, we witness a higher recognition of political alternative media in the US. After the inauguration of President Donald Trump, some right-wing media received press credentials for the White House, for example the Gateway Pundit blog (Grynbaum 2017). Apart from smaller alternative media organizations, Breitbart News Network became one of the leading news sites for conservatives in the US. The use, spread and impact of such alternative media will be a major issue for media scholars and political scientists to study in the near future.

Further research should continue to analyze the relationship of populist alternative media and mainstream media to observe possible changes in the dependence of alternative media on content of established journalism. Furthermore, general and ongoing studies on the field positions of alternative media actors could be useful to identify powerful players in the alternative media field. A field-centered approach could be a reasonable basis to determine the power positions which arise from inequitable allocations of cultural, social, and economic capital (Bourdieu 1992, 58). Influential populist media outlets like Breitbart in the US, Avpixlat and Fria Tider in Sweden or Kopp in Germany could be ranked higher in the alternative media field whereas smaller blogs or individual websites are less powerful. An ongoing measurement of that field could give scholars the possibility to make predictions for the future communicative framework in democratic societies.

\section{References}

Aalberg, T., Esser F., Reinemann C., Strömbäck, J. and De Vreese, C. (2016). Populist Political Communication in Europe. London: Routledge.

Alvares, C. and Dahlgren, P. (2016). Populism, Extremism and Media: Mapping an Uncertain Terrain. European Journal of Communication, vol. 31(1), pp. 46-57.

BDZV (2016). Rückblende: BDZV kritisiert tätliche Angriffe auf Journalisten. Available at:

http://www.bdzv.de/nachrichtenundsevice/presse/pressemitteilungen/artikel/deta il/rueckblende_bdzv_kritisiert_taetliche_angriffe_auf_journalisten/ [Accessed 15 December 2016]

Berry, M., Garcia-Blanco, I. and Moore, K. (2016). 'Press coverage of the refugee and migrant crisis in the EU: a content analysis of five European countries. UNHCR. Available at: http://www.unhcr.org/56bb369c9.html [Accessed 15 December 2016]

Bourdieu, P. (1992). 'Ökonomisches Kapital - Kulturelles Kapital - Soziales Kapital.' In: M. Steinrücke (ed.). Schriften zu Politik \& Kultur. Die verborgenen 
Mechanismen der Macht, pp. 49-79. Hamburg: VSA-Verlag.

Capoccia, G. (2002). Anti-System Parties A Conceptual Reassessment. Journal of Theoretical Politics, vol. 14(1), pp. 9-35.

Ceron, A. and Memoli, V. (2015). Flames and Debates: Do Social Media Affect Satisfaction with Democracy? Social Indicators Research, vol. 126(1), pp. 225240.

Durchgezaehlt.org (2016). Klickern, Zählen und Schätzen. Available at: https://durchgezaehlt.org/ [Accessed 15.12.2016]

Grynbaum, M. (2017). White House Grants Press Credentials to a Pro-Trump Blog. Available at: https://www.nytimes.com/2017/02/13/business/the-gatewaypundit-trump.html?_r=0 [Accessed 15.12.2016]

Hellström, A. and Lodenius A.L. (2016). Invandring, mediebilder och radikala högerpopulistiska partier i Norden. Stockholm: DELMI.

Holt, K. (2016). “Alternativmedier"? En intervjustudie om mediekritik och mediemisstro. In: L. Trudeson (ed.). Migrationen i medierna - Men det får en väl inte prata om? pp. 113-149. Stockholm: Institutet för mediestudier.

Holt, K. (2016). Journalistik bortom redaktionerna?. In: Kulturdepartementet., Människorna, medierna \& marknaden. SOU 2016:30. Medieutredningens forskningsantologi om en demokrati $i$ förändring, pp. 403-428. Stockholm: Wolters Kluwer.

Haller, A. and Holt, K. (2016). The Populist Communication Paradox of PEGIDA: Between "Lying Press" and Journalistic Sources. 66th annual ICA conference "Communicating with power". Fukuoka, Japan, 9-13 June, Preconference: Populism in, by, and Against the Media.

Jagers, J. and Walgrave, S. (2007). Populism as Political Communication Style: An Empirical Study of Political Parties' Discourse in Belgium. European Journal of Political Research, vol. 46(3), pp. 319-345.

Mazzoleni, G. (2014). Mediatization and Political Populism. In: F. Esser and J. Strömbäck (eds.). Mediatization of Politics: Understanding the Transformation of Western Democracies, pp. 42-61. London: Palgrave MacMillan.

Mudde, C. (2004). The Populist Zeitgeist. Government and Opposition, vol. 39(4), pp. $542-563$.

Storz, W. (2015). "Querfront" - Karriere eines politisch-publizistischen Netzwerks. OBS-Arbeitspapier. Otto Brenner Stiftung. Available at: https://www.ottobrennershop.de/uploads/tx_mplightshop/AP18_Storz_2015_10 _19.pdf [Accessed 15.12.2016]

SZ-Online (2016). Pegida verliert Facebook-Seite. Available at: http://www.szonline.de/sachsen/pegida-verliert-facebook-seite-3450503.html [Accessed 15.12.2016]

Taguieff, P. (2015). La revanche du nationalisme: néopopulistes et xénophobes à l'assaut de l'Europe. Paris: Presses Universitaires de France. 
Truedson, L. (2016). Migrationen i medierna - Men det fär en väl inte prata om? Stockholm: Institutet för mediestudier.

Trump, D. (2016). Yet more evidence of a media-rigged election. Retrieved from https://twitter.com/realDonaldTrump [Accessed 15.12.2016]

Tsfati, Y. (2003). Media skepticism and Climate of Opinion Perception. International Journal of Public Opinion Research, vol. 15(1), pp. 65-82.

Welker, M. and Wünsch, C. (2010). Methoden der Online-Forschung. In: W. Schweiger and K. Beck (eds.). SpringerLin : Bücher. Handbuch Online-Kommunikation, pp. 487-516. Wiesbaden: VS Verlag für Sozialwissenschaften. 